var imidlertid ikke bare en mild og ufarlig sykdom, den kunne også være farlig og en sjelden gang drepende. En rekke pasienter havnet på intensivavdeling.»»

Ulvestad har så langt ikke kunnet dokumentere at helsemyndighetenes kommunikasjon var egnet til å skape frykt, at myndighetene mente å skape frykt, og at hensikten var å øke oppslutningen om vaksinasjon.

\section{Preben Aavitsland}

preben@epidemi.no

Preben Aavitsland (f. 1963) er lege ved Epidemi, Kristiansand. Interessekonflikter: Preben Aavitsland hadde sentrale roller i Folkehelseinstituttets håndtering av svineinfluensapandemien og i instituttets egenevaluering av håndteringen.

\section{Litteratur}

1. Swensen E. Jakten på det utenomjordiske. Tidsskr Nor Legeforen 2014: 134 $1230-2$

2. Direktoratet for samfunnssikkerhet og beredskap. Ny influensa A (H1N1) 2009 Gjennomgang av erfaringene i Norge. Tønsberg: DSB, 2010. (http://dsb.no/ Global/Publikasjoner/2010/Rapporter/PandemiRapport.pdf) (5.8.2014).

3. Gøystdal AM Venter mild, men langvarig pandemi. Oslo. NTB 1.5.2009.

4. Westerveld J, Thorgrimsen TCS, 100000 nordmenn er smittet. Oslo: Aftenposten, 22.10.2009. (http://aftenposten.no/nyheter/100000-nordmenn-er-smittet5588325.html\#.U-CsZZUcRaQ) (5.8.2014)

5. Ulvestad E, Swensen E, Simonsen GS et al. Pandemien - bidrag til etterpåklokskap. Tidsskr Nor Legeforen 2010; 130: 169-71.

\section{Re: Jakten på det utenomjordiske}

At helsemyndigheter spiller på frykt for å få folk til å handle adekvat overfor en overhengende fare, anser jeg som legitimt og uomgjengelig. Frykt er en bedre iverksetter av handling enn rasjonell innsikt, og dessuten er det umulig å formidle et budskap om fare uten samtidig å så et anstrøk av frykt - de to er tett sammenvevd. Derfor finner jeg det heller ikke kontroversielt at helsemyndighetene brukte frykt for å justere sitt budskap under pandemien, slik det går frem av et intervju med daværende helsedirektør Bjørn-Inge Larsen (1).

Mitt kritiske utsagn i intervjuet i Tidsskriftet var ikke rettet mot helsemyndighetenes bruk av frykt som virkemiddel, men snarere at de gjorde «illegitim bruk av frykt for å få folk til å vaksinere seg». Slik illegitim bruk av frykt vil kunne oppstå dersom det er manglende samsvar mellom reell fare og frykten som aktivt eller passivt formidles. Jeg lar meg overbevise av Aavitsland når han hevder at helsemyndighetene aldri hadde en intensjon om å så illegitim frykt $i$ befolkningen. Men informasjonen som ble gitt var forvirrende og ikke sjelden motstridende. Dermed ble budskapet ut til befolkningen mangetydig. Og mangetydighet, forsterket med et varsel om massevaksinasjon mot et virus som helsemyndighetene hevdet ikke var allmennfarlig, bidro knapt til å dempe forvirringen og dermed frykten.

I oktober 2009 sto myndighetene overfor et dilemma - de ønsket sterkt at hele folket skulle vaksineres, men kunne ikke nå målet dersom de samtidig gikk aktivt ut for å dempe frykten. De valgte å gå for massevaksinasjon, og dermed lot de trusselbildet henge som et uforløst damoklessverd over befolkningen. Siden helsemyndighetene var klar over virusets lave faregrad, kan denne unnfallenheten vanskelig betegnes som annet enn «illegitim bruk av frykt».

\section{Elling Ulvestad}

elling.ulvestad@helse-bergen.no

Elling Ulvestad (f. 1958) er professor og avdelingssjef ved Mikrobiologisk avdeling, Helse Bergen

Ingen oppgitte interessekonflikter.

\section{Litteratur}

1. Kråkenes C. Myndighetene ville kommunisere usikkerhet. NRK 9.3.2010. www.nrk.no/fordypning/myndighetene-onsket-usikkerhet-1.7030193 (10.8.2014)

\section{Re: Jakten på det utenomjordiske}

Ulvestad presiserer nå omsider sin påstand: Det var «illegitim bruk av frykt» at helsemyndighetene anbefalte befolkningen å vaksinere seg mot svineinfluensa uten at man «samtidig gikk aktivt ut for å dempe frykten» som han mener fantes i befolkningen.

Her har Ulvestad låst seg fast i sin forestilling om stemningen i befolkningen og helsemyndighetenes kommunikasjon. Som jeg har vist i denne debatten, forsøkte helsemyndighetene gjennom intervjuer, nettsider og åpne rapporter til helsetjenesten å formidle et nøkternt og realistisk bilde av epidemien. Den eksterne evalueringen konkluderte at «befolkningen i stor grad ble sikret informasjon som var konsistent og troverdig» (1).

Dermed var frykten i befolkningen i oktober 2009 ikke større enn at bare én av fem tenkte å vaksinere seg. Det kan indikere at helsemyndighetene hadde lykkes i å demme opp for fryktskapende journalistikk. Ja, faktisk hadde man nesten havnet i bagatelliseringsgrøften på motsatt side. Derfor valgte helsedirektøren «å forklare folk at riktignok er dette en mild pandemi, men det er allikevel alvorlig for noen, og det er grunn til å beskytte seg med en vaksine» (2).

Folkehelseinstituttets talsperson Bjørn Iversen fulgte opp i en rekke medier (3): «Dette viruset har to ansikter. Det har et mildt ansikt for de aller fleste, og så er det noen som blir veldig alvorlig syke.»

Instituttets åpne risikovurdering var: «Sykdomsbildet er overveiende mildt og letaliteten lik eller lavere enn ved sesonginfluensa, men komplikasjoner og dødsfall rammer unge voksne mer enn gamle. Vi antar at godt under $1 \%$ av de syke trenger sykehusinnleggelse, og at inntil $20 \%$ av disse trenger intensivbehandling.»

Aftenposten oppfattet budskapet (4): «For de aller fleste som smittes, er det snakk om en moderat influensa og ikke særlig annet. Men et ukjent antall tidligere helt friske personer, vil bli alvorlig syke og dø. Når man i forkant ikke kan peke på hvem disse er, har ikke myndighetene annet valg enn å anbefale vaksine til alle.»

Med Ulvestads ord ville budskapet ha vært (5): «Svineinfluensaen [er] imidlertid ikke bare en mild og ufarlig sykdom, den [kan] også være farlig og en sjelden gang drepende. En rekke pasienter [havner] på intensivavdeling.»

Mener da Ulvestad at den minimale forskjellen mellom hans eget og helsemyndighetenes budskap utgjør forskjellen mellom legitim og illegitim bruk av frykt?

\section{Preben Aavitsland}

preben@epidemi.no

Preben Aavitsland (f. 1963) er lege ved Epidemi, Kristiansand Oppgitte interessekonflikter: Preben Aavitsland hadde sentrale roller i Folkehelseinstituttets håndtering av svineinfluensapandemien og i instituttets egenevaluering av håndteringen.

Litteratur

1. Direktoratet for samfunnssikkerhet og beredskap. Ny influensa A (H1N1) 2009 Gjennomgang av erfaringene i Norge. Tønsberg: DSB, 2010. http://dsb.no/ Global/Publikasjoner/2010/Rapporter/PandemiRapport.pdf (14.8.2014)

2. Kråkenes C. Myndighetene ville kommunisere usikkerhet. NRK 9.3.2010. www.nrk.no/fordypning/myndighetene-onsket-usikkerhet-1.7030193 (14.8.2014)

3. Folkehelseinstituttet. Statusrapport om ny influensa A(H1N1), 23. oktober 2009 http://fhi.no/dokumenter/0c20db9282.pdf (14.8.2014)

4. Anonym. Gode råd. Aftenposten 24.10.2009

5. Ulvestad E, Swensen E, Simonsen GS et al. Pandemien - bidrag til etterpåklokskap. Tidsskr Nor Legeforen 2010; 130: 169-71.

\section{Re: Jakten på det utenomjordiske}

At Aavitsland ennå ikke har forstått mitt argument kan skyldes at jeg ikke fikk presisert tydelig nok at bruken av frykt var illegitim fordi den ble brukt til å fremme en dårlig begrunnet massevaksinasjon.

For meg er det fortsatt uforståelig at helsemyndighetene fant grunn til å anbefale massevaksinasjon i 2009. Hva angår kunnskap om smittevern, er norske myndigheter neppe unike i europeisk 